University of Nebraska - Lincoln

DigitalCommons@University of Nebraska - Lincoln

Sociology Department, Faculty Publications

Sociology, Department of

2011

Same-Sex Marriage in a Welcoming World: Rights Consciousness

of Heterosexuals in Liberal Religious Institutions

Emily Kazyak

University of Nebraska-Lincoln, ekazyak2@unl.edu

Follow this and additional works at: https://digitalcommons.unl.edu/sociologyfacpub

Part of the Sociology Commons

Kazyak, Emily, "Same-Sex Marriage in a Welcoming World: Rights Consciousness of Heterosexuals in Liberal Religious Institutions" (2011). Sociology Department, Faculty Publications. 157.

https://digitalcommons.unl.edu/sociologyfacpub/157

This Article is brought to you for free and open access by the Sociology, Department of at DigitalCommons@University of Nebraska - Lincoln. It has been accepted for inclusion in Sociology Department, Faculty Publications by an authorized administrator of DigitalCommons@University of Nebraska - Lincoln. 
Published in Sexuality Research and Social Policy 8:3 (2011), pp. 192-203; doi: 10.1007/s13178-011-0051-4

Copyright (C) 2011 Springer Science + Business Media, LLC. Used by permission.

Published online May 26, 2011.

\title{
Same-Sex Marriage in a Welcoming World: Rights Consciousness of Heterosexuals in Liberal Religious Institutions
}

\author{
Emily Kazyak
}

Department of Sociology and Program in Women's and Gender Studies, University of Nebraska-Lincoln, 725 Oldfather Hall, Lincoln, NE 68588, USA; email ekazyak2@unl.edu

\begin{abstract}
Previous research suggests that gays and lesbians not only look to the law as an important site of social recognition but also pursue strategies to legitimate their relationships outside of the law, such as having commitment ceremonies in religious institutions. While previous research suggests that homosexuality is a divisive issue within religious communities, we know little about how heterosexual religious people understand same-sex marriage. I aim to fill this gap and analyze the rights consciousness of heterosexual members in liberal religious denominations. Drawing on in-depth interviews, I examine how people make sense of the relationship between law and social change. While all interviewees support same-sex marriage, they express a contradictory understanding of how it should become legal in the USA. I analyze how they reconcile this contradiction within the context of their religious institutions.
\end{abstract}

Keywords: same-sex marriage, religion, legal consciousness, rights, Unitarian Universalism, United Church of Christ

The issue of same-sex marriage has garnered national attention in the USA within the last two decades. Although gay and lesbian couples took part in ceremonies to mark their commitment long before this attention (Chauncey, 1994; Lewin, 1998) and same-sex couples first applied for marriage licenses in 1970 (Chauncey, 2004; Cott, 2000; Graf, 1999), events over the past 20 years catapulted the issue of same-sex marriage onto the national cultural and political landscape. While the Defense of Marriage Act in 1996 federally defines marriage as between one man and one woman, at the state level, laws vary tremendously. Some states issue marriage licenses to same-sex couples, an outcome that has been reached through state legislatures votes (Vermont and New Hampshire) as well as through state Supreme Court decisions (Iowa, Massachusetts, and Connecticut). Other states offer alternative forms of legal recognition for same-sex couples, such as civil unions (New Jersey) or domestic partnerships (Wisconsin). Still other states have amended their state constitutions to ban same-sex marriage through voter-approved ballot initiatives, including the ballot initiatives in 11 states during the 2004 presidential election and the 2008 Proposition 8 initiative in California.

As these varied legal changes with regard to gay marriage illustrate, decisions about gay marriage have been reached at the federal and state levels and in legislative, judicial, and executive realms. Indeed, the question of how legalization of gay marriage should occur has been a focus in public discourse. Take, for instance, the recent voter decision in Iowa to remove three Supreme Court justices who were part of the decision to legalize gay marriage. The Iowa vote has been applauded by anti-gay marriage organizations like the National Organization for Marriage, whose president posits that judges wrongly "usurped the will of the people and imposed gay marriage" (National Organization for Marriage, 2010). The executive director of a pro-gay marriage organization, One Iowa, asserts that the courts are "there to protect the minority against the tyranny of the majority" (Sulzberger 2010). What about people outside social movement organizations or courtrooms? How do they make sense of gay marriage and the relationship between legal and social change? 
Employing a legal consciousness framework that focuses on how the law is understood by ordinary people in everyday life (Ewick and Silbey, 1998), I analyze in this article how heterosexuals make sense of gay marriage. Since religion and morality have been a focus in discussions about same-sex marriages and much attention has been given to conservative and evangelical Christian perspectives on same-sex marriage, the data presented here come from in-depth interviews with members of two liberal religious denominations. Given that all of the interviewees support marriage rights for same-sex couples, I do not focus on whether or not they support same-sex marriage. Rather, I ask: What are the narratives they use to describe what same-sex marriage means and how it should become legal? I demonstrate how a contradiction exists in their narratives about how same-sex marriage should become legal. Religious progressives express an understanding that legal change should and often does happen prior to social change, and therefore, same-sex marriage should be legal regardless of societal attitudes. However, they also express an understanding that social change should occur prior to legal change, and therefore, same-sex marriage should and will become legal only after the majority of people support it. I also ask: How do they reconcile this contradiction within their religious context? As religious progressives, they value the ability for an individual to decide his or her own morals and stress the importance of the democratic process. Furthermore, their experiences in congregations with welcoming policies toward gays and lesbians inform their optimism that the majority of people will support same-sex marriage in the future. Thus, while they support same-sex marriage, they believe that it is appropriate for decisions about it to be reached democratically and accept differing opinions about it. As they are unsatisfied with the current majority opinion with regard to same-sex marriage, yet also are not interested in imposing their opinion on others, religious progressives believe that the majority opinion will eventually change. Before turning to these findings and discussion, I outline the theoretical frameworks and the existing literature that ground this research and detail the research methods and data on which this paper is based.

\section{Literature Review}

\section{Legal Consciousness}

Sociolegal studies articulate the need to analyze the relationship between law, rights, and social context (Galanter, 2006; Garth and Sterling, 1998). While debate exists about the nature of that relationship and the extent to which rights matter (e.g., McCann, 1996; Rosenberg, 1996), many argue that rights, social context, and consciousness are mutually constitutive (e.g., Ewick and
Silbey, 1998; Harrington and Yngvesson, 1990; McCann, 1994; Ygnvesson, 1993). In this way, rights are emblematic of communication, meaning-making, and social inclusion. Rights are a communal discourse that individuals draw on to make sense of who they are and what they deserve and to convince others about how they should be treated (Minow, 1987; Williams, 1987). Thus, the contestation of the meaning of rights take place not only in courtrooms or among those directly pursuing social change, but also in everyday life (Ewick and Silbey, 1998; Merry, 1990; Sarat and Kearns, 1993). As research addresses the meanings of rights in everyday life, the goal should not be only to outline people's everyday understanding of the law, but also to analyze what made those perceptions possible and the effects of such perceptions (Silbey 2005). Scholars have pursued this line of inquiry to analyze rights consciousness across a range of topics, including disability (Engel and Munger, 2003), fatness (Kirkland, 2008), work (McCann, 1994), and same-sex marriage (Harding, 2006, 2008; Hull, 2006).

Hull (2006) finds that the law is an important site for many gays and lesbians and that the legal recognition of marriage is desired not only for its practical benefits but also for the perceived social and cultural legitimacy of the law. She also argues that gay and lesbian couples enact alternative forms of legality outside of official law through acts such as having public rituals or ceremonies and using terms like "spouse" or "wife" to describe their same-sex partners. She explains that couples often turn to religious institutions when having a public ritual, and thus, "religion often functions as an alternative to the state as a source of legality" (Hull, 2006, p. 652). Given that many gays and lesbians look to religious institutions as site to enact legality, it is important to understand how heterosexual members in such religious institutions understand this move and how they interpret same-sex marriage more broadly. Moreover, much of legal consciousness scholarship often looks at how people make sense of law as they think about pursing or actively pursue their own rights claims. The study shifts attention away from how individuals think about their own rights to a focus on how people make sense of others' rights claims, which is particularly important given an understanding of rights as a communal discourse.

\section{Religion, Politics, and Sexuality}

A number of scholars have analyzed the intersection of religion, politics, and sexuality in American society (e.g., Davis and Robinson, 1996; Hunter, 1991; Olson and Carroll, 1992; Wuthnow, 1988). Some argue that "the culture wars," a "war" characterized by divisions over religion and morality that translate into the political sphere, is exaggerated and that the liberal-conservative religious split does not translate neatly into a liberal-conservative political divide 
(Davis and Robinson, 1996; Olson and Carroll, 1992). However, nearly all scholars point to sexuality, specifically homosexuality, as a divisive issue within religious communities and as an issue around which leaders and members mobilize within congregations and in the political sphere (Cadge et al., 2007, 2008; Cadge and Wildeman, 2008; Ellingon et al., 2001; Moon, 2004; Stein, 2001).

In fact, religion often occupies a central focus in explaining opposition to same-sex marriage. Consider, for instance, the discussions following the 2004 presidential election that linked the passage of constitutional amendments that ban same-sex marriage in eleven states with voters' "moral values." Analyses indicate that, in fact, those who indicated that moral values are an important priority are more likely to be opposed to same-sex marriage (Olson et al. 2006). Research has focused on why and how conservative and evangelical Christians mobilize around anti-gay politics (Irvine, 2005; Linneman, 2004). Among the rhetoric that anti-gay organizations use in their activism include language such as "homosexual activists" and "liberal courts" (Irvine, 2005, p. 10). Linneman (2004) illustrates how the rise in anti-gay sentiment among conservative Christians stems from the fact that this population sees themselves as facing an environment that is increasing hostile. Specifically, they understand progress for gays and lesbians to be linked to their own marginalization.

The bulk of this literature analyzes Evangelical or Mainline Protestant denominations and focuses on the current struggles congregations face when dealing with homosexuality. This focus reflects a limitation, particularly given that there is variation within religious traditions with respect to views on same-sex sexuality and not all religious traditions oppose same-sex marriage or mobilize around anti-gay activism. Churches that emphasize social justice can often provide a context to advocate for social change and rights for sexual minorities due to their unique position outside of legal and state realms (Howe, 2007). Furthermore, many denominations have adopted official policies welcoming gays and lesbians for decades and have supported same-sex marriage, including the United Church of Christ and the Unitarian Universalist Association,,$\underline{1}$ but there has been little scholarly attention paid to such denominations. Moreover, we know relatively little about how religious people make sense of same-sex marriage. By analyzing the rights consciousness of heterosexual members of liberal religious congregations, this article attempts to fill these gaps.

\section{Gay and Lesbian Sexuality in a Post-Closet World}

That debates about same-sex marriage are occurring in American politics reflects an increasing consciousness in the public imagination about gays and lesbians (Gamson, 1998; Walters, 2001). Seidman (2002) terms this moment a "post-closet" one insofar as gays and lesbians are no longer living double lives or denying their sexuality. Rather, gay and lesbians are accepting their sexual identity and integrating it into the rest of their social lives. Seidman also draw attention to the fact that the normalization process around gay and lesbian identity is true only for some gays and lesbians - namely, those who are "gender conventional, well adjusted, and integrated into mainstream society; she is committed to home, family, career and nation" (p. 14). Furthermore, Seidman notes that the transformation of gay and lesbian life is incompletein interpersonal, cultural, and institutional realms - and highlights contradictions in the "post-closet" life. Despite being able to live beyond the closet, gays and lesbians also live in a world of "heterosexual domination" - in where "heterosexuals enjoy a privileged, superior social status that is secured by the state, social institutions, and popular culture" (Seidman, 2002, p. 6).

One of the ways that heterosexuality is privileged at the state level is reflected in the fact that the model citizen is implicitly defined as heterosexual (Richardson, 1998). There is considerable debate about the desirability and the consequences of efforts to contest this definition of citizenship by advocating for same-sex marriage (e.g. Ettelbrick, 1997; Eskridge, 1996; Stoddard, 1997; Warner, 1999). Access to equal citizenship is predicated on assertions that gays and lesbians are good, normal, and respectable and have relationships that mirror heterosexual ones (Richardson, 2004). Similarly, access to equal citizenship maintains the public/private binary insofar as the respectable gay and lesbian in the public sphere is desexualized (Richardson, 2004; Warner, 1999). In effect, the notion of the public citizen as an "abstract, disembodied" individual (Lister 1997, p. 70) is not challenged in efforts to legally recognize same-sex marriage.

That the Unitarian Universalist (UU) and United Church of Christ (UCC) congregations studied in this research, which have policies that welcome gays and lesbians, and the fact that same-sex couples do not have the right to marry highlight the contradictory moment of beyond the closet life. How then do heterosexuals who support same-sex marriage, but are living in a context where that right is not conferred to gays and lesbians make sense of the meaning of rights and the relationship between social and legal change?

1. The UU and the UCC denominations adopted the "welcoming" and "open and affirming" policies toward gays, lesbians, and bisexuals at the national level in 1989 and 1985, respectively. These denominations have also passed resolutions in support of the right for same-sex couples to marry (Unitarian Universalist Association, 1996; United Church of Christ, 2005a). 


\section{Method}

The data analyzed in this article come from 19 indepth interviews that I conducted with heterosexual members of a UU and a UCC congregation located in two mid-size cities in the Midwest between May and August of 2005. The UCC congregation adopted the "open and affirming" policy in 1989 and was one of the first churches in the state to have such a policy. The UU congregation adopted the "welcoming" policy in 1992. Ministers of both congregations perform commitment ceremonies and religious marriage ceremonies for same-sex couples. In addition to similar stances on gay and lesbian issues, both the UU and the UCC describe themselves as liberal or progressive denominations (Unitarian Universalist Association, 2005a; United Church of Christ, 2005b). Unitarian Universalism as is a non-creedal religion; rather than a creed, there are seven principles the denomination promotes, including (1) the inherent worth and dignity of every person, (2) justice, equity, and compassion in human relation, (3) acceptance of one another and encouragement to spiritual growth in our congregation, (4) a free and responsible search for truth and meaning, (5) the right of conscience and the use of the democratic process within our congregations and in society at large, (6) the goal of world community with peace, liberty, and justice for all, and (7) respect for the interdependent web of all existence of which we are a part (Unitarian Universalist Association 2005b). UCC is a Christian denomination, though from its start "affirmed the ideal that Christians did not always have to agree to live together in communion" (United Church of Christ, 2005b). This openness across congregations could be what the minister at the congregation where I interviewed was referring to when stating that UCCs are understood by some as "Unitarian Universalists Considering Christ." Of course, this stance need not be a reflection of the UCC denomination as a whole, nor all UCC congregations, $\underline{2}$ but is important for the project at hand insofar as I analyze UCC alongside UU members.

To recruit participants, I announced my project during a service (at the United Church of Christ congregation) and placed an announcement in newsletters and service programs (at the Unitarian Universalist congregation). The announcements requested individuals who were members of the congregation and were willing to talk about their congregation's open and affirming or welcoming policy and their thoughts about political and social activism and change with regard to gays and lesbians. In this article, I focus on the 19 interviews I conducted with heterosexual-identified members of the congregations. The majority of these participants (13) were recruited from the UU congregation, and six were recruited from the UCC congregation. The sample includes 12 women and seven men who range in age from 40 to 87 , with the average age being 58 . The racial makeup of the sample is overwhelmingly white, with only one participant who described herself as Mestizo.

The interviews were semi-structured and followed an interview schedule that included questions about experiences in the congregation, the welcoming or open and affirming policy, and social and political action, including the anti-same-sex marriage ballot initiative. The interviews were audio-recorded and transcribed. I began the analysis by reading through each transcript and taking notes on the themes that were most interesting. Some of the topics that emerged in this process, which Emerson et al. (1995) refer to as "open coding," include that participants repeatedly characterized sexuality as a private, irrelevant attribute and that they placed importance on people's ability to determine their own truth and values. I then further coded within the topics identified in open coding, doing "focused coding" (Emerson et al., 1995). For instance, one theme that emerged from the focused coding within the topic of "importance of determining own truth" is that interviewees made clear distinctions between their denominations and the religious right. After coding the interview data, I wrote analytic memos that linked themes, which were then developed into the results below. This process that entailed reading each transcript, categorizing line-by-line once initial codes were generated, and returning to the coded data while writing, allowed for a close examination of the data. It allowed me to generate themes based on "member's meanings" and capture the understandings about same-sex marriage put forth by interviewees. At the same time, the codes produced and the themes delineated here reflect my research interests and are but some of the many that could have been generated (Emerson et al., 1995, p. 151). The quotes used are edited for the sake of clarity, and pseudonyms are used for each participant.

\section{Findings}

\section{Understanding of Rights}

According to members of liberal religious communities, there are two competing notions of what rights are: Rights are understood both as a reflection of majority opinion and as counter-majoritarian. The narratives that the interviewees used when talking about the

2. Indeed, the official denominations stance is not one of "considering" Christ but of belief: "We believe in the triune God: Creator, resurrected Christ, the sole Head of the church, and the Holy Spirit, who guides and brings about the creative and redemptive work of God in the world" (United Church of Christ, 2005c). 
right of marriage for same-sex couples reveal a tension about what that right would signify. In one understanding, legal recognition of same-sex marriage would be a reflection of societal acceptance; in another, it would be a reflection of a transcendence of contemporary anti-gay societal norms. In other words, while all interviewees were in support of same-sex marriage, their narratives revealed contradictory understandings about the relationship between social and legal change. Which change should come first? Does (and should) social change happen prior to legal change? Or does (and should) legal change spur changes in the social realm? Consistent with other legal consciousness scholarship (Ewick and Silbey, 1998), interviewees did not express only one understanding about law and social change.

\section{Majority Opinion Versus Counter-Majoritarian}

When discussing same-sex marriage, all of the interviewees talked about the public's opinions and values. When asked about what they thought would happen in the USA with regards to same-sex marriage, only two people mentioned the Supreme Court, while the others all discussed the majority and its role in democratically deciding the future of the issue. $\frac{3}{-}$ Thus, according to one understanding, rights are a reflection of the majority's morals and opinions, as expressed through a democratic vote. Brad clearly articulates a belief that the right of marriage for same-sex couples should be decided in such a fashion. Speaking of same-sex marriage, he said that he is "willing to let that be decided by the process that we have in place...I'd go with what the voters say on that." While he "would vote to have gay marriage," he also supports democratically deciding whether samesex couples should have the right to marry. Likewise, Melissa described that "[the status of gay marriage in the United States] unfortunately is not going to change because there are too many people whose very sincere beliefs are quite different from mine...in a democracy, that makes a big difference [because] the majority does rule." Bob also stressed the importance of the democratic process and stated that the country "needs to move" in a direction of valuing that process more:

This country was founded on the democratic process that grows out of an ideology that says people have a right to their point of view and that point of view needs to be widely shared and widely discussed. In the democratic process, we eventually take a position. I do not always get what I want, but it is the process that is more important. It is more important that we follow that democratic process, even if that may mean that some people may not get what they want.

These quotes underscore the understanding that the public does and should have a role in deciding which groups are deserving of rights and which groups are not. While these three interviewees, like all the participants, think that same-sex couples should be able to legally marry, they also express an understanding that it is important to uphold the opinions of the majority.

In talking about those against same-sex marriage, the majority of people blamed evangelical religious beliefs, ignorance, and lack of experience with gay people. Importantly, however, some pointed to changes in the legal landscape. For instance, Megan made sense of the passage of state amendments in 2004 that defined marriage as between one man and one woman as being a reaction to marriages performed in San Francisco. She says: "I think what made that happen was the...kinda in your face [of the San Francisco events]...I think that's how people took it...I think there was a backlash." Christine also commented that the issue of marriage for same-sex couples was pushed "too fast." In her view, gays and lesbians "should have stuck with [civil unions]...so that at least you had all the rights of a married couple... before you got into this next thing of marriage, which carries with it so much...baggage." These narratives reveal how people grapple with the question of legal and social change. They illustrate a concern with same-sex couples having the right to marry "too fast," or before there is societal change and a majority that supports same-sex marriage.

However, interviewees also articulated the understanding that rights are counter-majoritarian. Rather than being reflective of the majority's opinion, rights are understood to transcend contemporary attitudes. This transcendence was articulated in both legalistic and moral terms. Two people explicitly referenced the Supreme Court and the US Constitution when asked about what they thought would happen in the country in regards to same-sex marriage. Jeff for instance said:

I think hopefully the right Supreme Court justices will get a hold of this and see that there really isn't a place for the state in regulating these relationships. I think judges will have to make the right decision.

Jeff explained that if same-sex marriage is "up to the populace, I don't think we're gonna go very far."

3. I did not ask specifically about the role of the Supreme Court. However, following Engel and Munger (2003), my interest is in the narratives people draw on to make sense of the law. Therefore, the fact that the Supreme Court was not part of most people's narratives about gay marriage is telling, even though the Supreme Court might have been more salient in their narratives had I asked specifically about its role. In this way, the narratives presented in this section reflect people's understandings both of what would and should happen with regard to gay marriage. 
Heather similarly evoked a legalistic counter-majoritarian view of rights when she said "our Constitution believes we have rights."

The view that rights exist to counter "the populace" was also expressed in moralistic terms. Participants understood rights to be a reflection of moral truth that transcends contemporary attitudes. This conceptualization of rights was most salient when interviewees made "like race" arguments (Halley, 2000). The people I interviewed drew parallels between the experiences of gays and lesbians and African Americans as well as between same-sex marriage and interracial marriage. When explaining why she is "completely in favor of gay marriage," Melissa said "it means dignity and not being separated and treated differently. Same with racism; why treat someone differently because of their race? I see it as parallel." Shirley also analogized to race when talking about same-sex marriage. She recounted a personal exchange where someone she was talking with made a comment that gay groups were pushing the issue too fast. She explained: "I said [to the person making the comment], you sound like people talking about Blacks when they were going to civil rights [who said] 'just stay there under the bamboo tree and eat your watermelon, it's not time.' Come on. When is the time?" Shirley's story suggests an understanding that same-sex marriage should exist regardless of how the populace thinks. Christine compared her current support for same-sex marriage to when "people took a stand in support of marriage between black and white 40 years ago." Deborah echoed this understanding when she says "if people want to get married, let them get married...It shouldn't make any difference whether they're gay or lesbians or men or women or black or white." In these narratives, the right for same-sex couples to marry comes from a sense of equality and morality. Thus, although drawing on different sources, either legalistic or moralistic, interviewees articulated the understanding that rights are counter-majoritarian. In these narratives, legal change with regard to granting rights to a minority should happen regardless of majority opinion.

\section{Material and Social Benefits}

Interviewees articulated an understanding that the right of marriage for same-sex couples would carry both material benefits and social benefits. For some, the material benefits afforded to spouses, such as access to healthcare or pensions, were significant aspects of marriage. Megan expressed: "I don't think marriage is sacred. I think marriage is a civil agreement between two people." Jeff likewise articulated the importance for same-sex couples to be able to enter into marriage because "when you get into property and economic means, there needs to be some clarity of the agreement."
He explained that being married means that the state recognizes that relationship and can protect the parties involved in the event of divorce, through things like spousal and child support. For this reason, Jeff thinks that same-sex marriage should be legal. In addition, Brad said: "I'm a little cynical about issues of principle... and I think what marriage of same-sex people is all about really has to do with the economic attributes of a marriage." While not agreeing that material or economic benefits were the only important aspect of marriage, others did mention things like spouses having access to healthcare as an important reason why same-sex marriage should be legally recognized.

Additionally, people discussed social benefits that accompanied marriage. While Megan viewed marriage as a civil agreement that affords certain economic benefits, she also addressed the following reason when explaining her support of same-sex marriage: "it makes perfect sense if people love each other and are in a relationship, marriage is what is accepted in our community as the way you show that." Given the fact that marriage affords couples recognition from society, Megan thinks gay and lesbian couples should be able to marry. Likewise, Charles commented: "when you get a marriage license from a county clerk, that is a symbolic acknowledgment that society accepts what you're proposing to do. So I think it's an important symbol of acceptance in society." These quotes underscore the understanding that the right of marriage entails not only economic benefits but also the social benefits of being recognized by others in your community as a legitimate, loving, committed couple.

Like gays and lesbians (Hull, 2006), heterosexuals in "post-closet" institutional contexts such as UCC or UU congregations do still imagine rights as being about societal acceptance and as being important sites where people's identities and lives are validated, despite being part of congregations that recognize samesex marriages. However, their narratives reveal a tension between same-sex couples being able to announce their love and commitment and society recognizing that declaration. In other words, as the following quote from Charles illustrates, it is precisely because he understands rights to symbolize societal acceptance that he wavers about the importance of gays and lesbians having the right to marry, even though he himself thinks they should. Talking about gay couples getting married, Charles says: "There's a subtle distinction between being able to declare it and having the rest of society recognize it. To me, the right to declare it without fear or persecution is a much more important thing than having society recognize it." While Charles supports same-sex marriage, he also maintains a view that it would mean societal acceptance, something he is more hesitant to embrace as a goal worthy of achieving. 
The narratives offered by Charles and other interviewees highlight the following contradiction about the relationship between social and legal change. According to one understanding, social change should occur prior to any legal change: Same-sex couples should and will have the right to marry after the majority of people accept and support that right. However, at the same time, their narratives also reveal an understanding that legal change should and often does happen prior to change in societal attitudes: Same-sex couples should and will have the right to marry regardless (and before) of societal attitudes. Therefore, how do people justify this apparent contradiction in their understanding about same-sex marriage? Below, I address how these reconciliations happen within the institutional and social context of their religious congregations.

\section{Reconciling Contradictions}

\section{Religious Values in Political Life and the Freedom to Decide}

When asked about the role they thought religious beliefs or values should play in political life, interviewees stressed the importance of the separation of church and state and also expressed frustration about politicians trying to use religion to garner support. However, all but one person thought an individual's religious beliefs or values should play a role in how they vote. In other words, respondents want religious and moral values part of people's decisions in the political realm. Cindie explained that "all the decisions I make, I make knowing what my faith belief is, so I do think it's very important." Heather agreed that "I think if we stand for justice and if we stand for peace that has to carry into everything we do, whether it's political or work related or how we spend our time or volunteering or spending money." Jeff also articulated this belief that "voting consistent with ones' religious beliefs, say, pro-choice or not, is legitimate." Melissa also thinks that religious beliefs affecting political participation is inevitable and "in many ways a positive." Andrea was the only person who thought individuals should not consider their religious beliefs when voting or making political decisions but should rather "transcend" them "in order to make sure society takes the course that is good for everybody." However, the majority of participants stressed the importance of individuals participating in political life in such a way that connects with their religious beliefs or values.

In addition, interviewees stressed that individuals must have the freedom to decide their own truth and values, even if it fundamentally disagrees with their own position. This position is informed by both their religious beliefs and identity and their desire to distance themselves from religious conservatives. When talk- ing about the importance of recognizing the diversity of opinions and granting others the freedom to decide what is true for them, the Unitarian Universalists interviewees drew on the UU principle of "free and responsible search for truth and meaning." George explained that UUs "believe in individual freedom and in people making up their own minds." United Church of Christ participants were more likely to reference their understanding of the Bible or Jesus when talking about the belief that everyone should have the freedom to make their own decisions and that there is no one truth. For instance, Cindie explained that: "my personal philosophy is that no where in the Bible do I have instructions to judge anyone. What you do here on earth, you're going to deal with God on later. It's not my position to tell anybody they're right or wrong on anything they do. It's that-judge not lest ye be judged." Although they drew on different sources to explain why, members of both religious groups were adamant that individuals should have the freedom to do and believe what they think is right.

The hesitancy to offer an absolute judgment of other's actions or beliefs was also informed by a desire to distance themselves from religious conservatives, who were often described as being a part of the "religious right." The following example from Charles most clearly underscores this theme. He explained that he is "troubled" by the religious right because of "their claim to have the one and only right answer," not because they are "a group of people with a particular point of view who are choosing to act collectively." He further explained that "I don't think that religious groups should be attempting to impose or proclaiming that they have the corner on truth. So I would not advocate organizing Unitarians to say, no we have the right answer." He thinks the claim to absolute truth is wrong, whether that be from the religious right or from Unitarian Universalists. While Charles thinks religious groups should be able to say "these are the ideals that we live by and we invite you to join our community and live by our values," nothing further should occur if a person responds with "no thank you, I have my own values." He says at that point, each side "should accept the right of the other to exist and have rights and opportunities in society." Charles is committed to a world where people with differing opinions co-exist and do not impinge on each other's rights and opportunities. He idealizes a fair society and a society with multiple truths and values. His quotes underscore the importance that interviewees place on both allowing an individual the freedom to decide her own values as well as on disavowing any claim to have an absolute truth.

Since interviewees upheld individual freedom, they often not only acknowledged but also legitimated beliefs that fundamentally opposed their own. For in- 
stance, when talking about people who oppose samesex marriage and are uncomfortable with gay people, Melissa responded with the following: "Well, they believe it's wrong. Just the same way I don't want to have war, [gay marriage] is the equivalent to them. They simply believe that there's a negative effect, the same way I think killing and fostering violence has a negative effect. I think they're not necessarily hateful. I think their expression, to me is hateful, but I think they simply have a conviction that [gay marriage] is destructive, [the] same way I see war as destructive." Melissa certainly does not agree with the belief that being gay is wrong nor that same-sex marriage will be destructive, but in this quote, she grants those beliefs the same legitimacy as her belief that war is destructive. Similarly, Christine asserted that "there are some people who are totally uncomfortable with homosexuality. They cannot give a logical reason, they just are uncomfortable and cannot be accepting. And I don't know what you do about that, nothing! You can't legislate how somebody feels, and, it would be folly to try." Christine's quote suggests that it would be a folly (and ineffective) for legal changes to precede social changes with regard to attitudes toward homosexuality and same-sex marriage.

In this way, her quote, along with the others presented in this section, demonstrates how interviewees reconcile the contradictory understanding about samesex marriage within the context of their religious institutions. The majoritarian view of rights is strengthened by the belief that individuals should have the freedom to decide their own values and the ability to demonstrate those values through voting. Discrediting the opinions of those who are anti-gay marriage would be akin to claiming only one truth, which religious progressives see as the problematic territory of religious conservatives. Therefore, while participants support the right for same-sex couples to marry, the meanings they make within their institutional religious context provide justifications for the understanding that rights do and should reflect the majority's opinion. Thus, it would be unsatisfactory for same-sex marriage to become legal when the majority of people oppose same-sex marriage. Of course, it would also be unsatisfactory if same-sex marriage never became legal. Interviewees are optimistic that change in opinions about same-sex marriage will happen through heterosexuals having more interactions with gays and lesbians, which will usher in a change in the legal realm. Again, the context of their religious institution, particularly its policy toward gays and lesbians, informs this optimism.

\section{Changing Opinions About Same-Sex Marriage}

All but one participant understood that personal experience, meaning daily interactions as well as watching television with gay characters, is an important way that opinions about same-sex marriage would change. For instance, George explained that "subtle day-today exchanges that people have" is mostly how personal beliefs about gay people and same-sex marriage shift. Positing how such a shift might occur, he said: "through encountering somebody and working with them....and they discover eight months later that he's gay. [They think], well, I like him, he's wonderful, so maybe being gay is not what I thought it was." Likewise, Katie thinks that those opposed to homosexuality "need to have relationships with people and grow to like them and then find out that they're gay." Thus, interviewees believe that experiences with gays and lesbians will lead to a progressive stance of being pro-gay and pro-same-sex marriage. They see their congregations as providing a space for such experiences to occur insofar as their congregations have a welcoming or open and affirming policy.

Indeed, participants understood their welcoming or open and affirming policy to reflect a progressive stance on sexuality. Katie thinks "our church is certainly more open than a lot of churches about [sexuality]." Dan also assigns Unitarian Universalism not only a progressive quality but also the responsibility to bring about change. He says that UUs are supposed to "bring people out of the dark ages." In talking about the UCC congregation's history being involved in welcoming people regardless of race or sexuality, Lynette says "I feel good about the things that this congregation is doing and always has done." However, their descriptions of what it means for heterosexuals to have experiences with gays and lesbians and of what their congregational policy means reveals an understanding that sexuality is an irrelevant, private, and unimportant characteristic. To notice or comment on one's sexuality is bad, and linking sexuality to sex is even worse.

According to the majority of interviewees, their congregation's policy means that sexuality does not matter and is a secondary characteristic. Talking about someone's sexuality, Bob explained that: "I don't really care and it basically doesn't make any difference to me. I don't consciously give it any thought." Lynette also described how she is open and affirming toward gays and lesbians in her congregation in the following way: "I don't view them differently, treat them differently, or respond to them in any different manner." She goes on to give the example that "if somebody new has started coming and someone asks, 'are they gay?' I'll say, 'I don't know, it doesn't matter.'" In these quotes, not caring about someone's sexuality equates to perhaps not even thinking it is important to know about it. This indifference about one's sexuality extends beyond the congregations as well. Rachel, for instance, asserted that "I have a lot of friends who are of a different orientation from me. I don't look at them that way. They're just my friends. I could care less who they go home with." Like- 
wise, a story retold by Melissa underscores the understanding that to talk about someone's sexuality, or even to give it any thought, is bad. When I asked if she had ever heard a group of middle schoolers to whom she had taught religious education say anything homophobic, she shared the following story about hearing them talk about someone who won a local competition. She explained:

They were telling me which one won and his sexuality came up. I remember somebody said 'he's gay' and then somebody else said 'no he's bi[sexual].' And I didn't say it, but I [thought] my God, this kid's lost all privacy of his sexuality because he won this contest. So it was a very accepting, even though it was gossip basically, there was a very accepting attitude as well. But still, I found that interesting that it was a topic of conversation...I mean, who cares about his sexuality? I think he deserves to not have that be the thing that comes up when people are talking about his winning. I just don't think that anybody needs to have their sexuality as a topic of others' conversation. Why make that a topic? Especially when you're not judging it negatively. It was almost like a sensationalist thing.

According to Melissa, even though the students were not saying anything negative about the winner's sexuality nor were making fun of him, but were rather mentioning it as one descriptor of who he was, she thinks they were out of bounds. For her, any discussion of someone's sexuality is sensationalist because no one should care about it.

The story retold by Melissa resonates with the how interviewees talked about the ideal way that attitudes towards same-sex marriage would change. People who are anti-same-sex marriage need to interact with gays and lesbians so they can realize that, as George put it, "being gay is not what I thought it was." However, in the ideal interaction, sexuality remains unacknowledged, so as to foster the ability for someone who is homophobic to like someone is who gay before knowing about their sexuality. Across all these stories, acknowledging someone's sexuality (too soon or in some cases, ever) in interpersonal interactions is negative, as sexuality should be an irrelevant characteristic. Interviewees are optimistic that such experiences will lead to a more accepting stance on same-sex marriage. In fact, they reconcile the tension in how they think social and legal change should be related by relying on this optimistic view that societal attitudes will change through interpersonal interactions. Not satisfied with the current majority opinion with regard to same-sex marriage, and also not interested in imposing their opinion on others, people justify this tension by pointing to a belief that the majority opinion will eventually change. They see the existence of their congregation's policies toward gays and lesbians as one thing that might help facilitate such change.

\section{Discussion and Conclusion}

Building on past research that has analyzed how gay and lesbians interpret the right of marriage (Harding, 2006, 2008; Hull, 2006) and how religious communities have struggled with and responded to homosexuality (Cadge et al., 2007, 2008; Cadge and Wildeman, 2008; Ellingon et al., 2001; Moon, 2004; Stein, 2001), this research asks how heterosexual in liberal religious congregations understand the right of marriage for same-sex couples. Given the small sample and recruitment techniques, these findings are not meant to be representative or generalizable. Rather, the strength of this method is in the fact that it provides an opportunity to highlight and analyze the nuanced, contradictory narratives people have about law and social change. The data presented above underscore the competing way that rights are understood: Rights for citizens are understood to be both a reflection and transcendence of the majority's opinions. While respondents support same-sex marriage, they also support, perhaps more adamantly, an individual's freedom to decide his or her own truth. Participants also want religious and moral values part of people's decisions in the political realm. These findings suggest that the tension between majoritarian and counter-majoritarian view of rights is only augmented given the importance placed on an individual's freedom to both decide and act based on his or her own truth. Participants think that same-sex couples should have access to marriage, yet their narratives reflect a hesitancy to claim to have an absolute truth or to force their values or beliefs on anyone else, whether those beliefs are about war or same-sex marriage. Doing so would mean participating in tactics they associate with religious conservatives and find unacceptable. While they view themselves as having a more progressive and enlightened stance on same-sex marriage, their understandings reflect a fine line between advocating for same-sex marriage and going too far in forcing other's into agreement on the issue. Rather, they hope that the majority opinions about same-sex marriage will change as more heterosexuals have personal experiences with gays and lesbians.

It is important to address the timing of my study. All of these interviews were conducted in a state whose voters 6 months earlier had approved a ballot initiative that changed the state Constitution with the following amendment: "To secure and preserve the benefits of marriage for our society and for future generations of children, the union of one man and one woman in marriage shall be the only agreement recognized as a marriage or 
similar union for any purpose." This recent passage no doubt shaped the understandings that people articulated in the interview. As interviewees discussed their understandings about rights and the extent to which they are counter-majoritarian, they were doing so within a context where the majority of people had just approved a ban on the state recognizing the marriages of same-sex couples. Had I conducted the interviews at a different time, participants might have addressed different court cases, for instance. However, their conflicted understanding about law and social change and the way they reconcile it provide some insights into how they might respond to the changes in the legal landscape that have since occurred since the time of the interviews.

The findings presented in this article are instructive for thinking about the future of same-sex marriage in the USA and the role that religious progressive might play in advocating for it. By focusing attention on two denominations that support same-sex marriage, this article serves as a reminder that being religious need not be synonymous with being against same-sex marriage or gay rights. In fact, in her research on the Metropolitan Community Church, Howe (2007) argues that churches might be better situated to advocate for gay rights than other organizations that are seen as advocacy-orientated. The religious progressives in this study want morals and religious beliefs to be a part of public policy discourse, including discussions about same-sex marriage. Many of them also drew on ideas about morality they thought should transcend contemporary anti-gay attitudes in explaining their support for same-sex marriage, thus signaling one potential avenue for bringing their "moral values" into public debates about samesex marriage. Future research could assess whether religious progressives assert similar explanations in public forums and how effective such assertions are vis-à-vis other religious people's perspectives.

This is not to suggest that the understandings of same-sex marriage among religious progressives, including the ones presented in this article, are not without problems. The findings presented here illustrate some of the potential issues that might arise for progressive religious organizations advocating for same-sex marriage. One of the barriers is the desire for progressive religious individuals to distance themselves from those they see as part of the religious right who claim absolute truth with regard to their stance on homosexuality and same-sex marriage. Fostering inter-faith dialogues might be one potential solution that would allow multiple religious perspectives on same-sex marriage to be heard. Having multiple perspectives might alleviate religious progressives' fear of imposing their opinion on others without allowing for dialogue.

Another potential limitation indicated by these findings is the understandings of sexuality offered by interviewees. While they support same-sex marriage and their congregation's welcoming policy toward gays and lesbians, they also see sexuality as something that should be kept in the private realm. Not only should sexuality be in the private realm, but it should also be unrecognized even there, as it is an irrelevant characteristic. By situating sexual identity as private, they conflate a public acknowledgement of gay or lesbian sexual identity with being anti-gay. Rather than use a logic of pain when talking about gays and lesbians (Moon, 2004), these liberal religious members use a logic that empties sexuality from having any meaning. Their narratives suggest a difference between heterosexuals and gays and lesbians that has implications for advocacy efforts. While some gays and lesbians are increasingly seeking public recognition of their relationships (and by extension, their sexuality) (Lewin, 1998; Hull, 2006), some progressive heterosexuals maintain that sexuality should be not thought or talked about. Thus, the understanding that being progressive means treating sexuality as irrelevant or unacknowledged seems to be contrary to the recognition that some gays and lesbians desire. Furthermore, the findings presented here also suggest a belief that the private sphere is seen as the proper site for sexual minorities to challenge public legal status. Public demonstrations are seen as leading to backlash, too "in your face," and not appropriate route given the emphasis on interpersonal interactions as the way to change attitudes. In this way, their narratives uphold a normative ideal of citizenship (Lister, 1997; Richardson, 2004; Warner, 1999).

I argue that such an understanding of sexuality underscores the contradictory and incomplete inclusion of sexual minorities in the "post-closest" contemporary moment (Seidman, 2002). In other words, the understanding of sexuality offered by these religious progressives is not necessarily unique to them. It does, however, have unique implications for thinking about how allies make sense of and advocate for same-sex marriage. It indicates that when talking about the lives of gays and lesbians (their friends, members of their religious community), supporters of same-sex marriage often struggle to find a language to talk about how and why sexuality might matter in those lives. In other words, can there be a way to both express support for same-sex marriage and also recognize how sexuality might in fact be very meaningful for interpersonal interactions and those individuals seeking rights? While Hull (2006) posits the possibility that engaging with the issue of same-sex marriage on moral terms and using personal stories to humanize the impact of the lack of recognition might help bolster supporters' claims, these findings suggest that in addition to moral terms, there might need to be cultural terms that allow for a richer account of gay and lesbian identity and life. Moreover, this research illustrates a tension in post-closet world for heterosexuals as they negotiate how to both welcome 
and accept gays and lesbians while simultaneously acknowledge their sexuality. Accordingly, one implication of this research for progressive religious organizations is the need to continue dialogue about what a welcoming or open and affirming policy might mean for samesex marriage advocacy.

Furthermore, this research highlights a component that contributes to ambivalence about same-sex marriage, even from people who support it. It shows that some heterosexual allies are ambivalent, though supportive, because of a concern about legal changes happening prior to the majority of people accepting same-sex marriage. Just as past research has shown contradictions among conservative Christians with regard to how they view same-sex sexual relations and gay rights (Linneman, 2004), or variation among religious individuals on specific gay right issues (Besen and Zicklin, 2007), this research shows contradictions among progressive religious people. While Hull (2001) found that supporters of same-sex marriage were likely to minimize the link between law and culture, the supporters in this study were very explicit about this link. In fact, it is precisely because of the tension in how rights are understood that creates ambivalence about same-sex couples having the right to marry prior to the majority of the public accepting it. Even though the people I interviewed support same-sex marriage, they also maintain a view that rights are and should be granted by the majority. Listening to these narratives indicates the need to be mindful about the ambivalence when advocating for same-sex marriage and discussing chances that have occurred with regard to same-sex marriage. Future research could analyze the question of when a counter-majoritarian view of rights is most effectively supported. For instance, given that current public support is much higher than it was when these interviews were conducted (Langer, 2011) and that some states have made same-sex marriage legal through legislative action, do allies understand same-sex marriage differently?

Finally, a related implication of this research is that it indicates that this is a fraught moment when talking about law's importance for sexual minorities - particularly around marriage. How to talk about law's importance in the daily everyday lives of sexual minorities presents a predicament. On the one hand, progressive religious allies see their congregations as places that accept gays and lesbians. This is important insofar as people share similar views to Charles, who indicated that he was more concerned with gays and lesbians being able to declare their love, ostensibly something they are able to do via being able to have a commitment ceremony, than have it recognized by society, via being able to get a marriage license. As gays and lesbians continue to enact legality outside of the law (Hull, 2006) and heterosexual allies support this by similar actions (e.g., going to commitment ceremonies, using "wife" or "son in-law" regardless of the legal status of marriage), how might there be a simultaneous advocacy for the importance of the law? In a similar vein, since religious progressives articulate their support for marriage by drawing on moral terms as well as by pointing to the material and social benefits of marriage, this research suggest that perhaps religious progressives might be less likely to recognize the psychological harm gays and lesbians experience as a result of not having access to marriage (Herdt and Kertzner, 2006). In other words, do religious progressives assume that any psychological harm is countered by having accepting spaces such as their congregations within which to celebrate their commitment? Future work could address this question. Moreover, since this research highlights diversity of opinions among religious people and the contradictions in surrounding ideas about the ideal relationship between the law and social changes, it indicates an important area that future work should continue to explore as the legal changes with regard to same-sex marriage continue to proliferate.

\section{References}

Besen, Y., \& Zicklin, G. (2007). Young men, religion, and attitudes toward homosexuality. Journal of Men, Masculinities, and Spirituality, 3, 250-266.

Cadge, W., \& Wildeman, C. (2008). Facilitators and advocates: How mainline Protestant clergy respond to homosexuality. Sociological Perspectives, 51, 587-603.

Cadge, W., Day, H., \& Wildeman, C. (2007). Bridging the denomination-congregation divide: Evangelical Lutheran Church in America congregations respond to homosexuality. Review of Religious Research, 48, 245-259.

Cadge, W., Olson, L., \& Wildeman, C. (2008). How denominational context influences debate about homosexuality in mainline Protestant Congregations. Sociology of Religion, 69, 187-207.

Chauncey, G. (1994). Gay New York: Gender, urban culture, and the making of the gay male world, 1890-1940. New York: Basic Books.

Chauncey, G. (2004). Why marriage? The history shaping today's debate over gay equality. New York: Basic Books.

Cott, N. (2000). Public vows: A history of marriage and the nation. Cambridge: Harvard University Press.

Davis, N., \& Robinson, R. (1996). Are the rumors of war exaggerated? Religious orthodoxy and moral progressivism in America. The American Journal of Sociology, 102, 756-787.

Ellingon, S., Nelson, T., Van Haitsma, M., \& Laumann, E. (2001). Religion and the politics of sexuality. Journal of Contemporary Ethnography, 30, 3-55.

Emerson, R., Fretz, R., \& Shaw, L. (1995). Writing ethnographic fieldnotes. Chicago: University of Chicago Press.

Engel, D. M., \& Munger, F. W. (2003). Rights of inclusion: Law and identity in the life stories of Americans with disabilities. Chicago: University of Chicago Press.

Eskridge, W. (1996). The case for same-sex marriage. New York: Free Press.

Ettelbrick, P. (1997). Since when is marriage a path to liberation? In W. N. Eskridge \& N. D. Hunter (Eds.), Sexuality, Gender, and the Law (pp. 817-818). Westbury, New York: The Foundation Press. 
Ewick, P., \& Silbey, S. (1998). The common place of law: Stories from everyday life. Chicago: University of Chicago Press.

Galanter, M. (2006). In the winter of our discontent: Law, anti-law, and social science. Annual Review of Law and Social Science, 2, $1-16$.

Gamson, J. (1998). Freaks talk back: Tabloid talk shows and sexual nonconformity. Chicago: University of Chicago Press.

Garth, B., \& Sterling, J. (1998). From legal realism to law and society: Reshaping law for the last stages of the social activist state. Law \& Society Review, 32, 409-471.

Graf, E. J. (1999). What is marriage for? Boston: Beacon Press.

Halley, J. (2000). 'Like-race' arguments. In J. Butler, J. Gilroy, \& K. Thomas (Eds.), What's left of theory: New works on the politics of literary theory (pp. 40-74). New York: Routledge.

Harding, R. (2006). "Dogs are 'registered', people shouldn't be": Legal consciousness and lesbian and gay rights. Social $\mathcal{E}$ Legal Studies, 15, 511-533.

Harding, R. (2008). Recognizing (and resisting) regulation: Attitudes to the introduction of civil partnerships. Sexualities, 11, 740-760.

Harrington, C. B., \& Yngvesson, B. (1990). Interpretive sociolegal research. Law ESocial Inquiry, 15, 135-148.

Herdt, G., \& Kertzner, R. (2006). I do, but I can't: The impact of marriage denial on the mental health and sexual citizenship of lesbians and gay men in the United States. Sexuality $\mathcal{E}$ Social Policy, 3, 33-49.

Howe, C. (2007). Sexual borderlands: Lesbian and gay migration, human rights, and the Metropolitan Community Church. Sexuality Research \& Social Policy, 4, 88-106.

Hull, K. (2001). The political limits of the rights frame: The case of same-sex marriage in Hawaii. Sociological Perspectives, 44, 207-232.

Hull, K. (2006). Same-sex marriage: The cultural politics of love and law. Cambridge: Harvard University Press.

Hunter, J. (1991). Culture wars: The struggle to define America. New York: Basic.

Irvine, J. (2005). Anti-gay politics online: A study of sexuality and stigma on national websites. Sexuality Research $\mathcal{E}$ Social Policy, 2, 3-21.

Kirkland, A. (2008). Think of the hippopotamus: Rights consciousness in the fat acceptance movement. Law \& Society Review, 42, 397-432.

Langer, G. (2011). Support for gay marriage reaches a milestone. $A B C$ News. Retrieved from http://abcnews.go.com/Politics/support-gay-marriage-reaches-milestone-half-americans-support/ story?id=13159608/

Lewin, E. (1998). Recognizing ourselves: Lesbian and gay ceremonies of commitment. New York: Columbia University Press.

Linneman, T. J. (2004). Homophobia and hostility: Christian conservative reactions to the political and cultural progress of lesbians and gay men. Sexuality Research \& Social Policy, 2, 56-76.

Lister, R. (1997). Citizenship: Feminist perspectives. New York: New York University Press.

McCann, M. (1994). Rights at work: Pay equity reform and the politics of legal mobilization. Chicago: University of Chicago Press.

McCann, M. (1996). Causal versus constitutive explanations (or, on the difficulty of being so positive). Law E Social Inquiry, 21, 457-482.

Merry, S. (1990). Getting justice and getting even: Legal consciousness among working-class Americans. Chicago: University of Chicago Press.

Minow, M. (1987). Interpreting rights: An essay for Robert Cover. The Yale Law Journal, 96, 1860-1915.
Moon, D. (2004). God, sex, and politics: Homosexuality and everyday theologies. Chicago: University of Chicago Press.

National Organization for Marriage. (2010). Marriage an historic winner at polls [Press release]. Retrieved from http://www. nationformarriage.org/site/c.omL2KeN0LzH/b.5075687/ apps/s/content.asp?ct $=8716865$

Olson, D., \& Carroll, J. (1992). Religiously based politics: Religious elites and the public. Social Forces, 70, 765-786.

Olson, L., Cadge, W., \& Harrison, J. T. (2006). Religion and public opinion about same-sex marriage. Social Science Quarterly, 87, 340-360.

Richardson, D. (1998). Sexuality and citizenship, Sociology, 32, 83-100.

Richardson, D. (2004). Locating sexualities: From here to normality, Sexualities, 391-411.

Rosenberg, G. (1996). Review: Positivism, interpretivism, and the study of law. Law \& Social Inquiry, 21, 435-455.

Sarat, A., \& Kearns, T. (1993). Law in everyday life. Ann Arbor: University of Michigan Press.

Seidman, S. (2002). Beyond the closet: The transformation of gay and lesbian life. New York: Routledge.

Silbey, S. (2005). After legal consciousness. Annual Review of Law and Social Science, 1, 323-368.

Stein, A. (2001). The stranger next door: The story of a small community's battle over sex, faith, and civil rights. Boston: Beacon Press.

Stoddard, T. (1997). Why gay people should seek the right to marry. In W. N. Eskridge \& N. D. Hunter (Eds.), Sexuality, Gender, and the Law (pp. 818-822). Westbury, New York: The Foundation Press.

Sulzberger, A.G. (2010). Ouster of Iowa Judges Send Signal to Bench. New York Times. Retrieved from http://www. nytimes.com/2010/11/04/us/politics/04judges.html? $\mathrm{r}=1 \& \mathrm{scp}=1 \& \mathrm{sq}=$ Iowa $\% 202010 \% 20$ supreme $\% 20$ court $\% 20$ elections\&st $=$ cse

Unitarian Universalist Association. (1996). Support of the right to marry for same-sex couples. Unitarian Universalist Association of Congregations. Retrieved from http://www.uua.org/socialjus$\underline{\text { tice/socialjustice/statements/14251.shtml }}$

Unitarian Universalist Association. (2005a). Beliefs within our faith. Unitarian Universalist Association of Congregations. Retrieved from http://uua.org/visitors/beliefswithin/index. $\underline{\text { shtml }}$

Unitarian Universalist Association. (2005b). Our principles. Unitarian Universalist Association of Congregations. Retrieved from http:/ / uua.org/visitors/6798.shtml

United Church of Christ. (2005a). Equal marriage rights for all. Retrieved from http://www.ucc.org/lgbt/statements.html

United Church of Christ. (2005b). About us. Retrieved from http://www.ucc.org/about-us

United Church of Christ. (2005c). What we believe. Retrieved from http://www.ucc.org/about-us/what-we-believe.html

Walters, S. (2001). All the rage: The story of gay visibility in America. Chicago: University of Chicago Press.

Warner, M. (1999). The trouble with normal: Sex, politics, and the ethics of queer life. Cambridge: Harvard University Press.

Williams, P. (1987). Alchemical notes: Reconstructing ideals from deconstructed rights. Harvard Civil Rights-Civil Liberties Law Review, 22, 401-433.

Wuthnow, R. (1988). The restructuring of American religion: Society and faith since World War II. Princeton: Princeton University Press.

Ygnvesson, B. (1993). Virtuous citizens, disruptive subjects: Order and complaint in a New England Court. New York: Routledge. 